\title{
Thyroid Stimulating Immunoglobulin
}

National Cancer Institute

\section{Source}

National Cancer Institute. Thyroid Stimulating Immunoglobulin. NCI Thesaurus. Code C129780.

An immunoglobulin that can bind to thyrotropin receptors expressed on thyroid gland cells and stimulates excess secretion of the thyroid hormones thyroxine (T4) and triiodothyronine (T3). 